\title{
KAKSKEELSE OSKUSSÕNASTIKU KOOSTAMISE TEOREETILISI VAATENURKI JA PRAKTILISI LAHENDUSI
}

\author{
Valentina Štšadneva ja Eve Raeste \\ Tartu Ülikool
}

Kokkuvõte. Kirjutises käsitletakse õdedele mõeldud kakskeelse oskussõnastiku (,Vene-eesti tervishoiu ja sotsiaaltöö sõnastik”) koostamise põhimõtteid ja vaadeldakse, kuidas need on realiseerunud kõne all olevas sõnastikus. Peatutakse probleemidel, mis kerkisid valdkondade piiritlemisel ja sõnavara valikul. Arvukate näidete varal keskendutakse keelendite vastendamisega seotud probleemidele ja nende võimalikele lahendustele. Sõnastiku koostamisel on välistatud lähenemisviis, mille järgi autori töö seisneb keelendite mehhaanilises tõlkimises sihtkeelde. Teaduslik lähenemine eeldab paljude üksikute ja üldiste lingvistiliste küsimuste lahendamist. Süsteemsuse ja adekvaatsuse saavutamiseks sõnastiku koostamisel töötasid autorid välja sotsiolingvistilised printsiibid, täpsustades $\mathrm{ka}$ oma lähenemisviisi mitmele vaidlusalusele keeleteoreetilisele probleemile (normatiivsuse tagamine terminoloogias, süsteemsus jt). Sõnastiku piiratud mahu tingimustes osutus valdkondi hõlmavate erialade seisukohalt erineva profiiliga õdede jaoks olulise sõnavara määratlemine äärmiselt keeruliseks (nt pereõde, opiõde, hooldusõde, erakoralise meditsiini õde, intensiivõde jne). Tuli lahendada sõnastiku alusmaterjali kvantiteedi ja kvaliteedi küsimus. Püstitatud eesmärk nõudis sõnastiku adressaadi staatuse, tervishoiu ja sotsiaaltöötajate igapäevasuhtluse ning keeleliste väljendusvahendite mitmekesisuse arvestamist. Artiklis vaadeldakse ka olulisimaid sotsiolingvistiliste teguritega seotud leksikograafilisi probleeme.

Märksõnad: kakskeelne oskussõnastik, oskuskeel, sotsiolingvistika, leksikoloogia, leksikograafia, termin, keeleõpe, eesti keel, vene keel

Abstract. Professionally focused bilingual dictionary (on the basis of the compilers' experience). The article discusses the principles of 
the compilation of a professional dictionary ("Russian-Estonian Dictionary of Health Care and Social Work") for nurses and the application of these principles in practice. The authors consider the problems of differentiation between various branches of medicine and the choice of lexis. In the compilation of a dictionary an approach whereby the author mechanically translates linguistic items into the target language is out of the question. A scientific approach requires the solution of many specific and general linguistic problems. In order to achieve systematicity and adequacy the authors developed sociolinguistic principles and specified their approach to a number of disputed issues in linguistic theory (the assurance of normativity in terminology, systematicity, etc.). Due to spatial limitations the selection of relevant professional vocabulary covering various branches of medicine proved a challenge. The question of quantity and quality of source material required a solution. The objective demanded the consideration of the status of the addressee, the everyday communication of health care and social workers and the diversity of means of expression. The article also examines important lexicographical problems connected to sociolinguistic factors.

Keywords: professionally focused bilingual dictionary, Estonian for specific purposes, sociolinguistics, lexicology, lexicography, term, language teaching, Estonian, Russian

\section{Sissejuhatus}

Artikli eesmärk on anda ülevaade ,Vene-eesti tervishoiu ja sotsiaaltöö sõnastiku" koostamisega seotud probleemidest, nende lahendamise võimalustest, juhtides tähelepanu raskustele, mille ületamiseks tuleb kakskeelse sõnastike koostajail valmistuda. Vaatluse all on kakskeelne normatiivne sünkroonne oskussõnastik ${ }^{1}$.

Käsitletava oskussõnastiku esimene väljaanne on valminud Phare projekti „Eesti keele oskuse arendamine mitteeesti õppekeelega kutsekoolides“" osana 2005. aasta novembris, mil kutsekoolide õpilaste tarbeks anti välja ,Vene-eesti turismi-

1 Vt O. Palikova väitekirja „Kakskeelne sõnaraamat ja sõna funktsionaalsed seosed", mis on uusim uurimustöö kakskeelse sõnastiku koostamisest. 
ja puhkesõnastik“ ja „Vene-eesti tervishoiu ja sotsiaaltöö sõnastik". Viimati nimetatud sõnastiku täiendatud ja parandatud trükk ilmus 2007. aastal ja selle sihtrühmaks on erineva profiiliga õed.

Kõne all oleva sõnastiku koostamise seisukohalt on olulised sotsiolingvistilised tegurid, mille taustal arutletakse artiklis lingvistiliste probleemide üle. Kuivõrd leksikograafia-, keele- ja grammatikaküsimuste lahendamine sõltub sõnastiku koostamisel selle sotsiolingvistilisest baasist, eeldab lingvistilistele probleemidele lähenemise viis üksikasjalikku peatumist sõnastiku jaoks olulistel mittelingvistilistel küsimustel. Just viimaste lahendamine dikteerib esimeste lahendusviisi. Arvestades lingvistilise aspekti ulatuslikkust, saame selles kirjutises vaadelda vaid kõige olulisemaid küsimusi.

\section{Sõnastiku koostamise sotsiolingvistilised lähtalused}

\subsection{Sõnastiku koostamise üldpõhimõtted}

Peatuksime lühidalt neil küsimustel, mis kerkisid autorite ette sõnastiku koostamise lähtealuste määratlemisel.

Mis tahes kakskeelne sõnastik on suunatud eeskätt suhtlusoskuse edukale arendamisele keeles, mida omandada soovitakse. Samuti on kakskeelne õppesõnastik orienteeritud õppeprotsessi toetamisele. See tähendab, et sõnastik aitab tulevasel spetsialistil oskuskeele õppimise kaudu eriala omandada. Sellist eesmärki silmas pidades tuleb õppesõnastiku koostamisel lähtuda alljärgnevatest teguritest (vt joonis 1):

Autorite jaoks ei olnud olulised mitte ainult 1) sõnastiku sihtrühm ja 2) valdkonna eripärast tingitud suhtlustemaatika, vaid ka 3) sõnastiku etteantud maht, mis piiras autori vabadust sõnastiku koostamisel, ja 4) väga pingeline kohustuslik ajagraafik, arvestades valdkonna mahukust. Eraldi tuleks märkida 5) subjektiivsusfaktorit e autorite enda vaatenurka sõnastiku sisu ja vormi küsimustele, kusjuures erinevalt oskussõnastike koostamise tavapraktikast püüdsime lähtuda oskussõnastiku mudelist, mille alustalaks on mõiste, mitte sõnaloend (Tavast 2002: 403-404). 


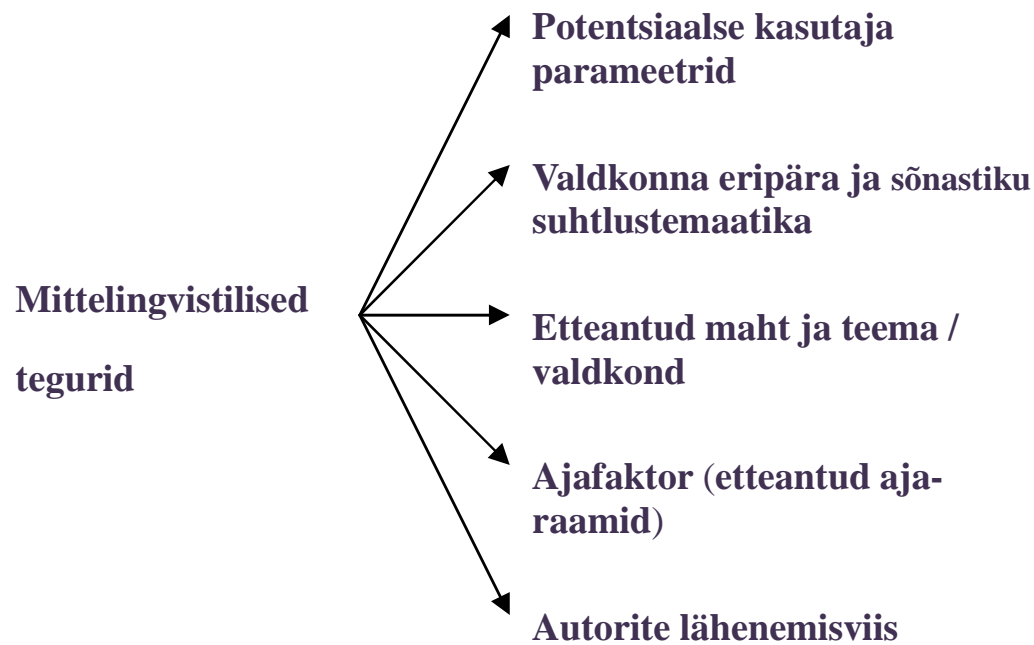

Joonis 1. Õppesõnastiku koostamise mittelingvistilised tegurid

Vaadeldav sõnastik on mõeldud eeskätt vene keelt kõnelevale kasutajale, kes valdab vähe või ei valda üldse sõnastiku sihtkeelt (käesoleval juhul eesti keelt). Ideaalis on kakskeelse sõnastiku potentsiaalseks kasutajaks mõlema keele esindajad, harvemini ka mõnda teist keelt kõnelev inimene näiteks poolakas, kes valdab vene keelt ja kes vajab keelelist tuge eesti keele õppimisel. Et vältida võimalikke eksimusi, näiteks interferentsete verbide kasutamisel, on sõnastikus püütud arvestada neid keelelisi ja grammatilisi iseärasusi, mis interferentsi tulemusena osutuvad vene keelt kõnelevale kasutajale veakriitilisteks. Nimetagem siinkohal selliseid veaohtlikke verbe nagu ${ }^{2}$

(1) заболева́ть / заболе́ть* haigestu/ma, -da, -n, -takse, haigeks jääma, haigeks jääda, jään haigeks, jäädakse haigeks;

2 Näidete illustreerimisel on mõningaid sõnaartikleid lühendatud ruumi kokkuhoiu eesmärgil. 
де́ти заболева́ют гри'ппом ча́ще взро́слых lapsed haigestuvad grippi sagedamini kui täiskasvanud (vrd haigestuma gripiga) ${ }^{3}$

(2) задыха́ться / задохну́ться* lämbu/ma, -da, -n, takse; уга́рным га́зом vingugaasi kätte lämbuma (vrd lämbuma vingugaasiga)

(3) возде́йствовать mõju[s]ta/ma, -da, -n, -takse, toimi/ma, -da, -b; на биоакти'вные то́чки bioaktiivseid punkte mõju[s]tama (vrd mõjuma bioaktiivsete punktide peale); на ребёнка ла́ской last hellusega mõju[s]tama

või termin ravikurss)

(4) курс [ravi]kuur, -i, -i, -е; лече́ния ravikuur (vrd

Kuna sõnastiku koostamisel on silmas peetud ka eestlastest kasutajaskonda, kes sooviksid oma vene keele oskust erialavaldkonnas täiendada, siis oli vajalik arvestada mitte ainult sihtkeele, vaid ka lähtekeele eripära ning raskusi, millega eestlasest keeleõppija kokku puutub, näiteks verbi perfektiivne ja imperfektiivne aspekt, nimisõnade muutevormistik, sõnarõhk ja selle muutumine - kõiki neid iseärasusi oleme püüdnud sõnastikus kajastada. Nii näiteks on vene keeles sõnarõhul ka grammatiline tähendus, seetõttu antakse vene sõnade vormid regulaarselt koos sõnarõhuga. Sõnarõhu olulisust illustreerib sõnaartikkel бело́к:

(5) бело́к, белка́, мн. ч. белки', белко́в val/k, -gu, -ku, -ke; просты'е белки', протеи'ны lihtvalgud, proteiinid; сложные белки', протеи'ды liitvalgud, proteiidid; обнару́живать / обнару́жить* бело́к в моче́ uriinist valku leidma

Et grammatikaküsimused ei ole artikli keskseks uurimisobjektiks, siis ei vaadelda neid eraldi peatükis.

3 Näidete puhul on artiklis antud sulgudes allajoonituna kõige sagedamini esinevad vead. Vigaseid vorme ei ole sõnastikus antud. 
Grammatilist infot antakse sõnastikus valikuliselt, kuid süsteemselt kogu sõnastiku ulatuses ${ }^{4}$. See puudutab nii eesti kui ka vene keelt. Kasutaja ei pruugi süsteemsust esmapilgul märgata, kuivõrd infot antakse erineval moel ja raamatu kogumahu foonil see nii selgelt ei avaldu. Grammatikamärgendid on esitatud näiteks juhtumite puhul, mis on seotud lekseemi omapäraga mõlemas keeles, seda veaohtlike tegusõnade ja ka nimisõnade puhul.

(6) фикси'р/овать, -ую, -уешь fikseeri/ma, -da, -n, takse; взгляд pilku fikseerima; внима́ние tähelepanu fikseerima; повя'зку sidet fikseerima; сло́манную коне́чность murtud jäset fikseerima

(7) парализ/ова́ть, -у́ет halva/ma, -ta, -b, -takse, paralüseeri/ma, -da, -b, -takse; пацие́нта парализова́ло по́сле инсу́льта haige sai insuldi tagajärjel halvatuse; у больно́го парализова́ло но́ги haigel on $v$ olid jalad halvatud

Vaieldamatult on igasugune keeleline info kakskeelses sõnastikus kasulik ja mida rohkem seda on, seda suurem on sõnastiku kasutusväärtus. Praktikas on just autorid need, kes keelelise, sh ka grammatilise info süsteemi viivad ning selle esitusviisi välja töötavad. Autorid kehtestavad ka vajalikud piirangud, mida raamatu trükiversiooni maht nõuab. Kuna meie sõnastiku maht oli esialgselt rangelt piiratud (3000 sõna), osutus valdkondi hõlmavate erialade sõnavara määratlemine äärmiselt komplitseerituks. Kerkis küsimus, kuidas piiratud mahu tingimustes hõlmata tervishoiu ja sotsiaaltöö spetsialistide kutsestandardiga ettenähtud ametialane terminoloogia, mida tulevane spetsialist tundma peab. Seega tuli lahendada sõnastiku alusmaterjali kvantiteedi ja kvaliteedi küsimus.

Püstitatud eesmärk nõudis keskendumist sotsiolingvistilistele teguritele, mis loob vajaduse arvestada sõnastiku potentsiaalsete kasutajate, s.o tervishoiu ja sotsiaaltöö spetsialistide

1) kutsetöös realiseeritavaid rollisuhteid:

\footnotetext{
${ }^{4} \mathrm{Vt}$,Vene-eesti tervishoiu ja sotsiaaltöö sõnastiku” juhendit lk 5-7.
} 
a) ametlik ametialane suhtlus

b) mitteametlik erialane suhtlus

c) mitteametlik igapäevasuhtlus;

2) sotsiaalse staatusega seotud erinevusi keelelistes väljendusvahendites - seega keele kogu semantilist ruumi koos selle tähendusi realiseeriva väljendvaraga (Kerge 2000: 88).

Niisiis on õe suhtlus mitmeplaaniline: see hõlmab erinevaid suhtlusolukordi muutuva adressaadiga. Öeldut kirjeldab joonis 2 .

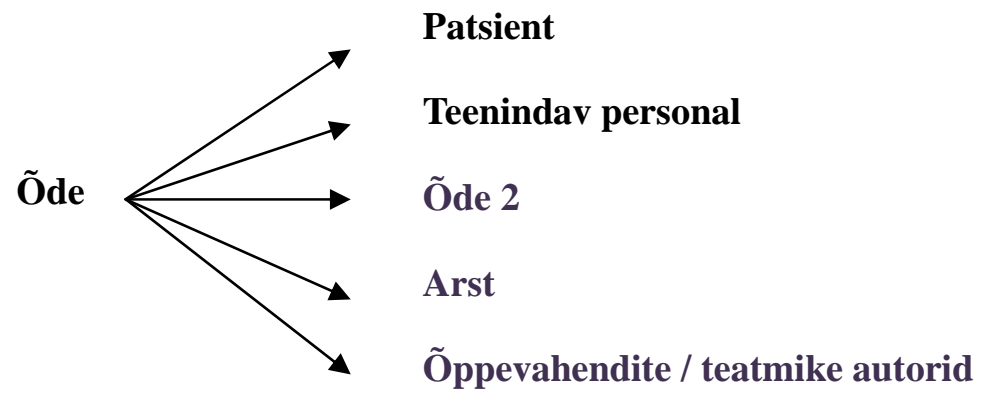

Joonis 2. Õe suhtlemise mitmeplaanilisus

Skeem illustreerib ilmekalt seda, et sotsiolingvistilisi tegureid, mis on mitmekesised ja nõuavad palju peamurdmist ka väiksemahulise väljaande puhul, ei tasuks alahinnata.

\subsection{Keelendite valikuprintsiibid}

Projekt nägi ette temaatiliselt heterogeense väljaande koostamise, kuna tervishoid haiguste ärahoidmise ning ravivaldkonnana hõlmab väga erinevaid meditsiinivaldkondi nagu füsioteraapiat, sünnitusabi, kirurgiat, terviseedendust ja veel palju teisi valdkondi. Lisaks tuli põimida väljaandesse ka sotsiaaltöövaldkond. On mõistetav, et kogu temaatikat 150 leheküljele A5 formaadis ära ei mahuta, seega seisime väga raske küsimuse ees: kuidas muuta sõnastik temaatiliselt 
homogeenseks ja terviklikuks? Me loodame, et see õnnestus 1) temaatiliste kitsenduste tõttu: nimelt jätsime piiratud mahu tõttu sõnastikust välja kliinilist meditsiini puudutavad terminid, sest need leiavad kajastamist ka rahvusvaheliste terminitena mis tahes meditsiinialases allikas; 2) pragmaatiliste kriteeriumide tõttu, mis tulenesid kutsestandardi nõudest tulevasele spetsialistile osata toime tulla oma kutsealal ning suuta selgitada erinevaid toiminguid eesti keeles, eeskätt meditsiiniteenuste osutamisel. Lõpptulemusena jõudsid sõnastikku keelendid, mis paigutuvad kahele tähendusväljale: meditsiin ja sotsiaaltöö.

Lisaks on sõnastikus antud ka ravimtaimede nimetusi. Esindatud on ainult need ravimtaimed, mis kasvavad Eestis ja mida kasutavad aktiivselt nii venelased kui ka eestlased, nt

(8) мать-и-мачеха paiseleh/t, -e, -te (Tussilago farfara)

Mis puutub sotsiaaltöö sõnavarasse, siis see on sõnastikus esindatud väiksemal määral - piirdutud on vaid selle osaga, mis põimub meditsiinivaldkonnaga. See tähendab, et sõnastikus on esitatud ainult niisugune sotsiaaltööga seotud leksika, mis kajastab õe mitmesuguseid toiminguid sotsiaalteenuste osutamisel või patsientide aitamisel, nt

(9) опе́к/a hooldus, -e, -t, hooldami/ne, -se, -st; eestkoste, -e, -t; изли'шняя $\sim$ a ülearune hooldamine; [üle]liigne hoolitsemine; о́рганы $\sim$ и и попечи'тельства hoolekandeasutused; hooldus-ja eestkosteasutused; брать / взять* под $\sim \mathbf{y}$ eestkoste alla võtma; hooldada $v$ hoole alla võtma; находи'ться под ой госуда́рства riikliku hoolduse all $v$ riigi hooldada olema; учрежда́ть / учреди'ть* $\sim \mathbf{y}$ eestkostet $v$ hooldust korraldama

(10) опеку́н hooldaja, -, -t, -id; eestkostja, -, -t, -id; быть о́м hooldajaks $v$ eestkostjaks olema; исполня'ть обя'занности á hooldaja $v$ eestkostja kohustusi täitma; назнача́ть / назна́чить* á hooldajat $v$ eestkostjat määrama; нужда́ться в áx hooldajaid $v$ eestkostjaid vajama; станови'ться / стать* о́м hooldajaks $v$ eestkostjaks hakkama 
(11) опеку́нск/ий hooldaja-; eestkostja-; hooldus-; eestkoste-; ая отве́тственность hooldaja vastutus; оe посо́бие hooldajatoetus; ая семья' hoolduspere

Et sotsiaaltöö terminoloogia on suhteliselt uus ja ühtlustamata, osutus selle kindlaksmääramine kõige keerulisemaks, kuna vene ja eesti keeles puuduvad valdkonnas üldkasutatavad sõnaraamatud, samuti paljud ei kattu valdkonna mõisted vene ja eesti mõisteruumis põhjusel, millest tuleb juttu allpool. Paljusid neist kasutatakse erineva aktiivsusega, nt

(12) хо́спис hospiits, -i, -i, -e; помещáть / помести'ть* больно́го в $~$ haiget hospiitsi paigutama

Tuleb märkida, et sõnastik on esialgu planeeritust umbes ühe kolmandiku võrra mahukam nende keelendite või leksikaalsete üksuste arvel, mis on aktuaalsed kõikide kasutajate seisukohast. Ühilduvuse näiteid tõime juba eespool. Olgu lisatud, et üksikutel juhtudel on toodud lausevormis näited, nt tegusõnaartiklis заменя'ть / замени'mь*, kus esikohal on infinitiivsed sihitisega ühendid ja viimasel kohal õe kutsetöös vajalik lausenäide.

(13) заменя'ть / замени'ть* asenda/ma, -da, -n, -takse; по́чку neeru asendama; часть сосу́да asendama osa veresoonest; кто мо́жет замени'ть меня' за́втра? kes saab mind homme asendada?

Enamasti lausenäited registris ei kajastu, välja arvatud need, mis on suhtlustasandil olulisemad. Seega ei ole üheks lähtealuseks mitte ainult lähtekeelse lekseemi vastendamine, vaid ka nende kasutusjuhtumite illustreerimine, kus see lekseem kõige sagedamini esineb - nii saame avardada kasutaja tarvis ka sõna mõistet. Et tõsta sõnastiku kasutusväärtust, ei ole sõnastikus toodud mitte ainult puhtad terminid, vaid ka arvukalt tervishoiu ja sotsiaaltöö valdkonna mõisteid, mis kõik üheskoos moodustavad semantilise välja meditsiin ja sotsiaaltöö. Nimetagem selle välja peamised üksused.

Esiteks nimisõnad - inimeste, esemete, meditsiinitarvikute nimetused, mis on vajalikud protseduuride 
läbiviimiseks, samuti õde ja patsienti ümbritsevate inimeste ja esemete nimetused.

(14) беспризо́рник, беспризо́рница hooldamata $e$ kodutu (-, -t, -id) laps (lapse, last, lapsi), tänavalaps

(15) апте́чк/a kodu-, matka-, reisi-, autoaptee/k, -gi, -ki, -ke; набо́р лека́рств для доро́жной и matka- $v$ reisiapteegi ravimikomplekt

(16) бахи'лы (обычно мн. ч.; ед. ч. бахи'ла) kattesuss/id, -ide, -e; хирурги'ческие kirurgi kattesussid; для посети'телей külastajate kattesussid; в медици'нских учрежде́ниях на у́личную о́бувь надева́ют meditsiiniasutustes tõmmatakse tänavajalatsite peale kattesussid

(17) ба́нк/a kup/p, -u, -pu, -ре; ста́вить / поста́вить* и kuppe panema; снима́ть / сня'ть* $\sim$ и kuppe eemaldama

(18) сто́лик (väike) lau/d, -a, -da, -du; пелена́льный mähkimislaud; процеду́рный protseduurilaud; хирурги'ческий kirurgi laud; стомато́лога stomatoloogi laud; для перевя'зочных отделе́ний sidumisosakonna laud

Siia kuuluvad ka abstraktsed mõisted, mida tervishoiutöötaja suhtluses kasutab.

(19) бед/á häda, -, -, -sid, õnnetus, -e, -t, -i; попада́ть / попа́сть* в $\sim$ ý hätta sattuma; в семье́ случи'лась á perekonnas juhtus õnnetus

(20) беспо́мощност/ь, -и abitus, -e, -t; по́лная ь täielik abitus; преодолева́ть / преодоле́ть* свою' ь ота abitusest üle saama

(21) беспризо́рност/ь, -и hooldamatus, -e, -t, järelevalvetus, -e, -t; борьба́ $\mathbf{c} \quad \sim \mathbf{b ю}$ võitlus (laste) järelevalvetusega

Teiseks omadussõnad, mis viitavad eritähendusi omavate substantiividega väljendatud mõistete kvaliteedile. Siia kuuluvad protsessid, toimingud, seisundid, omadused, esemed, inimesed jne.

(22) радика́льн/ый radikaal/ne, -se, -set, -seid, radikaal-; ое вмеша́тельство radikaalne sekkumine; ое 
лече́ние radikaalne ravi; aя мépa radikaalne abinõu; aя опера́ция radikaalne operatsioon; ый спо́соб radikaalne võte

(23) тяжёл/ый raske, -, -t, -id; ая боле́знь raske haigus; ый больно́й raske haige; ое дыха́ние raske hingamine; ая ра́на raske haav; ғые ро́ды raske sünnitus; ый сон raske, sügav uni; ое те́ло raske keha; ая фо́рма гри'ппа gripi raske vorm

Kolmandaks verbid, mis tähistavad õe või sotsiaaltöötaja toiminguid.

(24) бинтова́ть sidet tegema, sidet teha, teen sidet, tehakse sidet, (sidemega) siduma, siduda, seon, seotakse; го́лову pead siduma; сов. забинтова́mь

(25) вводи'ть / ввести'* manusta/ma, -da, -n, -takse; зонд в желу́док sondi makku juhtima, viima; лека́рство внутриве́нно ravimit veeni süstima

(26) уха́живать hoolitse/ma, -da, -n, -takse; põeta/ma, da, -n, -takse; за больны'м haige eest hoolitsema; haiget põetama; за ребёнком lapse eest hoolitsema; за ко́жей лица́ näonahka hooldama

Nagu näha, tekkis autoritel vajadus lähteprintsiipide järele, mis oleksid aluseks

1) sõnade ja eeskätt oskussõnade valikul,

2) ekvivalentide valikul,

3) leksikaalsete üksuste grammatilisel vormistamisel nii lähte- kui ka sihtkeeles,

4) sõnaartiklite tehnilisel vormistamisel.

Vääriks veel kord rõhutamist, et mittelingvistilised tegurid mitte ainult ei mõjuta kavandatu lingvistilist teostust, vaid sõna otseses mõttes dikteerivad selle.

\section{Sõnastiku koostamise keeleteoreetilised lähtealused}

Sõnastiku koostamisel tuli autoritel lahendada hulgaliselt üldisi ja üksikuid lingvistilisi küsimusi, mis on seotud mõlema keele puhul nii leksika kui ka grammatikaga. Vaatleksime olulisemaid neist. 
Kuna teadusliku stiili puhul on leksikaalse süsteemi tuumaks terminoloogia, mis ennekõike teenib akadeemilise suhtluse eesmärke, siis menutagem siinkohal, et mõiste termin (ladina terminus - äärmine, piir) on ühetähenduslik teadusvaldkonna nomenklatuuri kuuluv nimetusüksus sõna või sõnaühendi kujul, mis avab eseme, nähtuse või mõiste täpse sisu, mida ta tähistab (Kul tura russkoj rechi 2001: 170). Niisiis avab termini teaduslik definitsioon väga täpselt mõiste mõttelised osised. Terminisüsteemidega tegelevad spetsialistid on arvamusel, et ideaalis peab termin vastama tervele hulgale normatiivnõuetele (Kul tura russkoj rechi 2001: 197-204, Mereste 2000: 72-82 ja Kull 2000: 155-162), mida võib vaadelda kui nn ideaalsete terminite omadusi. Terminite normatiivnõuete käsitlemine on eraldi teema. Siin aga peatume lühidalt ainult kõige tähenduslikumatel nõuetel (printsiipidel), mis on tihedas omavahelises seoses. See on täpsus, ühetähenduslikkus ja sünonüümia puudumine.

Just meditsiiniterminoloogia puhul on ülioluline termini täpsus ja ühetähenduslikkus. Mõned lingvistid ja tõlkijad on meie arvates ekslikul seisukohal, millest lähtuvalt ei tekita terminite tõlkimine erilisi teoreetilisi probleeme. Nende arvates taandub sõnastiku autori ja/või tõlkija töö ekvivalentide mehhaanilisele leidmisele sihtkeeles. Seda seisukohta võiks pidada õigeks, kui kahe keele, s.o lähte- ja sihtkeele mõisteruumid täielikult kattuksid. Tegelikkuses on olukord teistsugune. Terminoloogiline vaste ei suuda alati hõlmata lähtekeelse termini mõistete tähendusruumi kogu mahus, seetõttu täpsuse ja ühetähenduslikkuse nõue alati ei kehti. Näiteks venekeelne sõna здравоохранение on pigem administratiivse tähendusega (erinevalt sõnaühendist охрана здоровья - tervisekaitse), eestikeelne vaste tervishoid aga pigem meditsiinilise tähendusega. Seega on nad vaid osalised ekvivalendid. See oligi üheks põhjuseks, miks sõnastiku venekeelses nimetuses sõna здравоохранение ei kasutata. Meditsiinis on ka mitmetähenduslikke termineid.

Ebamugav (vrd Vassiljeva 1976: 74) on kategoriaalne mitmetähenduslikkus, mis väljendub selles, et ühe terminisüsteemi sees tähistab üks ja seesama vorm nii protsessi kui ka resultaati, nt 
(27) оплодотворе́ние viljastami/ne, -se, -st, eostami/ne, -se, -st; viljastumi/ne, -se, -st, eostumi/ne, -se, -st; яйцекле́тки munaraku viljastamine; munaraku viljastumine

(28) отверде́лост/ь, -и tihkenemi/ne, -se, -st; tihkestus, e, -t, -i; на ме́сте уши'ба образова́лась ь äralöödud, haiget saanud kohas on moodustunud $v$ moodustus tihkestus; син. отверде́ние

(29) отверде́ние tihkenemi/ne, -se, -st; tihkestus, -e, -t, i; tihkend, -i, -it, -eid; небольшо́e väike tihkend, [kõva] tükk; син. отверде́лость

Eriti halb on see, kui terminil on mitu sisuliselt erineva tähendusega vastet, nt:

(30) аспира́ци/я 1. aspiratsioon, -i, -i, (kehaõõnest) äraimemi/ne, -se, -st, väljaimemine; я, отса́сывание содержи'мого желу́дка maosisaldise aspiratsioon, väljaimemine; производи'ть / произвести'* $\sim$ ю жи'дкости из дыха́тельных путе́й vedelikku hingamisteedest aspireerima, ära imema $\mathbf{2}$. aspiratsioon, -i, -i, hingamisteedesse tõmbami/ne, -se, -st; я части'ц пи'щи в дыха́тельные пути' toiduosakeste hingamisteedesse tõmbamine

Tuleb tunnistada, et täpsuse nõue ei kehti meditsiiniterminoloogias täheldatava keelesisese, samuti ka keeltevahelise sünonüümia korral. See on tõsine probleem, mille taha takerdusime ka meie oma töös. Nagu teada, on rahvusvaheliseks meditsiinikeeleks ladina keel. Kahtluse korral võtsime appi vene-ladina ja eesti-ladina sõnastikud, vaadeldes ladina keelt kui vahendajakeelt. See on ka põhjuseks, miks mõnedes sõnaartiklites on vene ja eesti lekseemid varustatud kreeka- ja ladinatüvelise terminiga ja vastupidi sõnastikus on esindatud mõlemad, vahest ehk käesolevas artiklis toodud näited seda väga selgelt ei illustreeri, nt

(31) абдо́мен abdoomen, -i, -it, kõh/t, -u, -tu, allkeha, -, ; син. жсиво́т, брюшна́я по́лость

(32) кровоточи'вост/ь, -и 1. veritsemi/ne, -se, -st, veritsus, -e, -t 2. veritsus/tõbi, -tõve, -tõbe, hemofiilia, -, -t; $с и н$. гемофили'я 
(33) те́танус [тэ'] teetanus, -e, -t, kangestuskramp/tõbi, tõve, -tõbe; син. столбня'к

Kuna sõnastiku koostamisel lähtusime teaduslikust lähenemisviisist, siis otsustasime sünonüümid anda ainult sel juhul, kui nad on tähenduselt võrdsed, st kui nad ei erine mõistemahult:

(34) нары'в (mäda)paise, -, -t, -id; mädanik, -u, -ku; гно́йный mädapaise; вскрыва́ть / вскры'ть* ска́льпелем paiset skalpelliga avama; созре́л paise on puhkemas; син. абсце́сс, гнойни'к

(35) обме́н веще́ств ainevahetus, -e, -t, metabolism, -i, i; белко́вый обме́н [веще́ств] valkude ainevahetus; жирово́й обме́н [веще́ств] rasvade ainevahetus; углево́дный обме́н [веще́ств] süsivesikute ainevahetus; проце́сс а веще́ств ainevahetusprotsess; нормализова́ть ainevahetust normaliseerima, korrastama; син. метаболи'зм

Üheks erandlikuks lingvistiliseks probleemiks osutus igapäevaleksika, st sõnad, mis kas vene või eesti keeles on oskussõnade argikeelsed / kõnekeelsed sünonüümid, nt:

(36) марганцо́вк/a разг. kaaliumpermanganaa/t, -di, -ti; раство́р $\sim \mathbf{H}$ kaaliumpermanganaadi lahus; син. марганцовоки'слый ка́лий, пермангана́т ка́лия

Sünonüümia mõistet terminoloogias ei saa tänini pidada üldiselt järgitavaks / üldtunnustatavaks. Nähtavasti on sünonüümidel oskuskeeles teine sisu ja teised funktsioonid kui üldkeeles (Kul'tura russkoj rechi 2001: 199). Sünonüümia all mõistetakse terminoloogias tavaliselt dubletsust (teisendamist), st jutt on keelenditest, mis oma tähenduselt kattuvad täielikult. Need on absoluutsed sünonüümid e teisendid e dubletid:

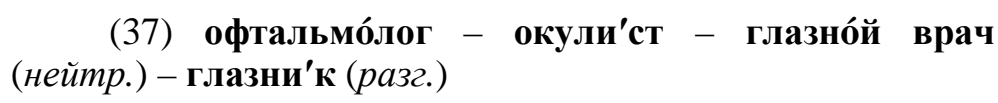

Kõnekeelne глазник kuulub sünonüümide hulka ainult seetõttu, et seisab teisendite (dublettide) reas. Kuid küsimust selle sõna kõrvaldamisest teisendite (dublettide) reast ei tõuse. 
Seevastu neutraalne liitsõnaline termin глазной врач pole meil sõnastikus üldse esindatud ja seda oma tavapärasuse tõttu, kuivõrd kuulub põhisõnavarasse.

Võrdsed sünonüümid e teisendid e dubletid ei sisalda semantiliselt mitte midagi uut ei üldkeeles ega teaduskeeles, seetõttu käsitletakse neid kui ebasoovitavat nähtust nende liigrohkuse või liiasuse tõttu (Vassiljeva 1976: 75). Kuid praktika, st elav keelekasutus näitab, et oskussõnadesünonüümide sisseviimine sõnastikku võib olla väga otstarbekas ja vajalik. Kui süsteemselt meie oma sõnastikus sellega hakkama saime, seda otsustab kasutaja. Igal juhul vaidles meie töörühm sünonüümide osas palju.

Sõnastiku koostamine ja ekvivalentide valik eesti keeles näitab, et sünonüümid-teisendid on väga mitmekesised. Näiteks sünonüümide rida meditsiini valdkonnas võib koosneda ainult laensõnadest mõlemas keeles:

mpu'nnep

(38) гоноре́я gonorröa -, -d, tripper, -i, -it; син.

Sünonüümide ritta võivad kuuluda mitu terminit, mõlemas keeles:

(39) окули'ст okulist, -i, -i, -e silmaarst, -i, -i, -е; син. офтальмо́лог, разг. глазни'к

(40) офтальмо́лог oftalmoloog, -i, -i, -e, silmaarst, -i, -i, -е; син. окули'ст, разг. глазни'к

(41) абдо́мен abdoomen, -i, -it, kõh/t, -u, -tu, allkeha, -, ; син. живо́т, брюшна́я по́лость

(42) абдомина́льн/ый abdominaal/ne, -se, -set, -seid, kõhtmi/ne, -se, -st, -si $e$-seid, kõhu-, kõht-; ая боль, боль в животе́ abdominaalne valu, kõhuvalu; ое дыха́ние, брюшно́е дыха́ние abdominaalne hingamine, vahelihasehingamine, van. kõhuhingamine; син. брюшно́й

Teisendite sisseviimise vajalikkust/olulisust kinnitavad ülaltoodud sõnaartiklid абдо́мен, абдомина́льный, kuna nendel samatüvelistel sõnadel on erinev sünonüümide kogum, kusjuures sünonüümide ühilduvus on erinev. Teisendite vajalikkuse määrab igal konkreetsel juhtumil terminisüsteemi funktsioneerimine. Meie näited illustreerivad seda, et lisaks 
dubletsusele, mis võimaldab oma ja laenatud oskussõna kasutamist, eksisteerib ka terminite stilistiline sünonüümia, nt разг. глазни'к. Kuid эпилепсия - падучая juhtum on jäetud sisse viimata põhjusel, et падучая on mitte ainult kõnekeelne, vaid ka madalkeelne ja vananenud sõna. Siinkohal peab täpsustama, et ei tohiks segamini ajada termini ajakohasust selle kasutamise sagedusega. On juhtumeid, kus tegelikult juba vananenud termin (nt окули' $\mathrm{cm}$ ) leiab valdkonnas üsna laialdast kasutamist, samal ajal kui ajakohane termin on vähekasutatav (офтальмо́лог - окули'ст).

Peatuksime ka oskussõnade lühivariantidel või -vormidel. Tänapäevale on iseloomulik just pikkade terminite loomine. Sõnaühendi nn lahtirullimisega antakse edasi kõige rohkem erialamõiste tunnuseid. Ühes sellega suureneb semantilise motiveerituse aste ja mõistetavus kontekstiväliselt. Kuid praktika dikteerib vajaduse asendada pikk ja kohmakas nimetus lühema variandiga, mis on kooskõlas keelevahendite ökonoomsuse printsiibiga (Mereste 2000: 63-73 ja Kul'tura russkoj rechi 2001: 202-203). Sellised funktsioonidelt võrdväärsed mõistete sekundaarsed tähised on esindatud ka meie sõnastikus erinevate abreviatuuridena:

(43) OP3 [оэрзэ'] (неизм., $\quad c p . \quad p.), \quad$ о́строе респирато́рное заболева́ние äge (-da, -dat) respiratoor/ne (se, - set) haigus $(-\mathrm{e},-\mathrm{t})$

(44) ОРВИ' [оэрви'] (неизм., ж. респирато́рная ви'русная инфе́кция äge (-da, -dat) respiratoor/ne (-se, -set) viirusnakkus (-e, -t)

\section{Kokkuvõte}

Eespool mainitud normatiivsed ettekirjutused peavad silmas ideaalset terminit ja sellepärast on praktikas vaja analüüsida igat juhtumit eraldi. Niisiis, et esitada sisu süsteemselt ja vastuoludeta, peame oskussõnastiku lingvistiliste lähtealuste väljatöötamisel täpsustama oma vaatenurga leksikoloogia vaidlusküsimustele, samuti arvestama mitmesuguseid keelelisi nähtusi. Kirjutisest jäid välja probleemid, mis on seotud ekvivalentsuse tüüpidega eestikeelsete vastete valikul. Samuti ei vaadelnud me 
grammatikaga seotud raskusi ja neist tulenevaid sõnakirjete vormistamise probleeme. On oluline märkida, et kõne all olevas väljaandes peegeldub autorite püüdlus nii aimata kui ka ületada leksikaalset ja grammatilist interferentsi. Kõik see väärib eraldi tähelepanu, seda enam, et erineval oskustasemel esinevad omad raskused. Lõpetuseks tahaks veel kord rõhutada, et lingvistiliste ülesannete lahendamine oskussõnastiku koostamisel tugines mittelingvistilistele teguritele, mis on loogiline ja vältimatu, siis võiksid tulevased autorid seda oskussõnastike koostamisel arvestada.

Aadressid:

Valentina Štšadneva ja Eve Raeste

slaavi filoloogia osakond

germaani, romaani ja slaavi filoloogia instituut

Tartu Ülikool

Näituse 2

50409 Tartu

E-mail: veeradm48@yahoo.com, valentina.schadneva@ut.ee;

Eve Raeste

keelekeskus

Tartu Ülikool

Näituse 2

50409 Tartu

E-mail: eve.raeste@ut.ee

\section{Kirjandus}

Kerge, Krista (2000) „Kirjakeel ja igapäevakeel“. Eesti keele allkeeled, 87101. (Tartu Ülikooli eesti keele õppetooli toimetised, 16.) Tartu: Tartu Ülikooli kirjastus.

Kull, Rein (2000) Kirjakeel, oskuskeel ja üldkeel, 148-162. Tallinn: Eesti Keele Sihtasutus.

Graudina, L. K., E. N. Shirjajev, otv. red. Kul'tura russkoj rechi (2001). (Rossijskaja Akademija nauk, Institut russkogo jazyka im. V. V. Vinogradova.) Moskva: Norma. 
Kakskeelse oskussõnastiku koostamisest 18

Mereste, Uno (2000) Oskuskeel ja seaduste keeleline rü̈̈, 57-286. Tallinn: Eesti Keele Sihtasutus.

Palikova, Oksana (2007) Dvujazychnyj slovar' i funktsional'no znachimye svjazi slova. Tartu: Tartu Ülikooli Kirjastus.

Raeste, Eve, Valentina Štšadneva, Eda Vaigla ja Natalija Karasjova (2005) Vene-eesti tervishoiu ja sotsiaaltöö sõnastik. Tartu ja Paide: Kuma.

Raeste, Eve, Valentina Štšadneva, Eda Vaigla ja Natalija Karasjova (2007) Vene-eesti tervishoiu ja sotsiaaltöö sõnastik. Tartu ja Paide: Kuma.

Tavast, Arvi (2002) „Eesti oskussõnastikud 1996-2000“. Keel ja Kirjandus 6, 401-414.

Vassiljeva, A. N. (1976) Kurs lekcij po stilistike russkogo jazyka. Nauchnyj stil' rechi. Moskva: Russkij jazyk. 
Kakskeelse oskussõnastiku koostamisest 19 